Lerotholi the allocation of lands is in the hands of chiefs, sub-chiefs, and headmen, and these have the power to take away lands from holders who do not cultivate them properly. People complain that they have no security, that their holding is dependent upon the favour of their chief; and in the National Council voices have been raised in favour of transferring to landboards the power of allocation and also asking for permanent individual tenure. The feeling of insecurity is possibly a hindrance to land improvement.

\title{
The Basutoland National Treasury
}

Writing in this Journal (October 1947) Dr. E. H. Ashton has referred to the two proclamations of 1938 as bringing the Native Authority of Basutoland 'unequivocably into the framework of government '. A further advance was made in 1946 by the establishment of a National Treasury. Its revenue, derived from a proportion of the taxation, from court fees, and fines, amounts to about $f, \mathrm{I} 20,000$. The plan was hammered out by a committee of the National Council. Since its constitution provided for the payment of salaries to chiefs and members of the courts, it was necessary to regulate their numbers. The Committee found that the existing 1,340 courts were greatly in excess of the need and proposed to reduce them to I 17. It was also ordained that fines should no longer go to the chiefs but be paid into the National Treasury. The effect of this enactment was considerably to reduce both the power and the income of many of the chiefs. The opening of the Treasury on I April r946 was probably the most important event in the recent history of the country.

During 1946 and 1947 Basutoland was shaken by a succession of trials for ' ritual murder'. The Times correspondent reported from Maseru on 24 October 1947 that seventeen Africans had that day been sentenced to death. Many others had preceded these. In all the cases it was shown that people had been killed for the purpose of getting their blood, or some other part of their body, for the making of 'medicine'. The Paramount Chief asked the National Council in October 1946 for advice how to put a stop to these murders. Some councillors put the blame upon 'witch-doctors' (as the English report of the debate calls them) and the Council passed a resolution that 'witch-doctors' should be made to stay in their villages and not move about. But other councillors were of the opinion that not the 'witchdoctors' but the chiefs were responsible. 'Councillor Lefela'-so runs the record-' strongly opposed the proposal to do away with witch-doctors, as he said that it was not proved that they were the cause of the murders, it being doubtful whether they persuaded the chiefs or whether the chiefs went to them first. He considered that restoring the position of the 1,300 chiefs, sub-chiefs and headmen, plus those others who had been omitted when these were gazetted, would stop the murders.' It is not at all impossible that there was a direct connexion between the establishment of the Treasury and the 'ritual murders '- that the chiefs whose power had been curtailed had recourse to 'medicine' to re-establish their power, 'medicine' of the requisite virtue only to be obtained from human bodies.

\section{African Place-names}

THe latest number of that excellent periodical The Uganda Journal (vol. $\mathbf{x}$, No. 2) is a reprint of articles which appeared in the five Bulletins issued during the war years 1943-5, when it was impossible to produce the Journal. Mr. R. A. Snoxall's paper on 'Some Buganda placenames' is of particular interest and raises questions which hitherto have been all too rarely studied. The names in Buganda have as prefixes KA-, WA-, NA-, and BU-. Of these BUis widely used as indicating ' country' as in 'Buganda' itself; the name of Busiro county means ' the country of tombs'. Thus, outside Uganda, we have Bwila, 'the country of the Ila people'. NA- is taken by Mr. Snoxall to be 'the feminine form corresponding to the 
masculine KA- of class IA '. It is usually said to be equivalent to 'mother of'. Namirembe, ' a very well known place of sanctuary in old Buganda in which a fugitive could not be molested ', would be literally ' the mother of peace'; Natete, 'mother of (place of) etete grass'; Nalubale, 'mother of the great spirit', is the name of Lake Victoria. The masculine prefix SE- corresponding to NA- might be rendered 'father of'; Seguku, 'the father of logs', is the name of a hill in Buganda on which grow massive trees which could not be carried away. Both these prefixes are found in personal names and also in place-names in other African countries. The locative A- or PA- takes the form of WA- in Ganda and occurs, says Mr. Snoxall, in the majority of truly descriptive geographical names, e.g. Wandegeya, 'the place of weaver birds'. The locative MU- ' is far from common 'in place-names; only one example is given, viz. Munsa, 'within the ditch'.

The prefix $\mathrm{KA}$ - is of particular interest. We have spent an idle hour in counting the names beginning with $\mathrm{Ka}$ in the index of The Times atlas so far as they are African-they number 260 and in all probability there are hundreds not recorded. They are found chiefly over a wide belt along the central axis running from Bechuanaland on the south to the AngloEgyptian Sudan, and also to a less extent in Nigeria, Dahomey, Ivory Coast, Liberia, Sierra Leone, and Senegal. What is the meaning of $\mathrm{KA}$ - in this context? Undoubtedly in many instances it is diminutive. Mr. Snoxall suggests that Kampala was originally $A$ kasozi ka-mpala, 'the little hill of the mpala antelope'. Kabira would be 'the nice little forest '; Kalungu, ' the little desert '. But, as Mr. Snoxall says, it is often difficult to see where the idea of smallness comes in. KA- has many other meanings. It is sometimes an honorific prefix as in Kabaka, Katekiro, the titles of the king and prime minister of Buganda; and it may be that many of the place-names are in reality titles or personal names; for example, Kazembe, which figures on the map as the name of a place in Northern Rhodesia, is properly the title of the chiefs whose capital that place was and is. $\mathrm{KA}$ - in some languages such as Zulu and Ila is a possessive particle used with personal names; thus in Zulu, Ka-Dinizulu means '(son) of Dinizulu'; and in Ila, isoko dya-ka-Shimunenga means 'the sacred grove of Shimunenga'. It is conceivable that some place-names have been formed by ellipsis, munzhi wa-ka-Mpanda, 'village of Mpanda', becoming Kampanda. KA- in many Bantu languages is a tense-particle, denoting past or future, and also imperative; and possibly some place-names may be sentences or the residue of proverbial phrases; e.g. Kamukamba might be a command to clap ( $k a m b a)$ the hands in sign of greeting or homage, and applied to a place where lived a great chief who had to be honoured in that manner. Mr. Snoxall suggests that KA- is often 'descriptive of a good place in which to find things', with no implication of smallness. 'The adjective 'good' would hardly apply to such a locality as Kakubansiri 'a place for mosquitoes'. It has been noted that in some languages $\mathrm{KA}$ - is a feminine or 'mother' prefix conveying the idea of bringing forth, producing, affording abundance of; and it is possible that the majority of place-names with that prefix carry such a suggestion. Mr. Snoxall instances Kabubbu, ' a good place for finding mbubbu grass '; Kamuli, 'a good place for reeds'; Kalisizo, 'a good place for pasture'. Thus outside Buganda: Kasenga, 'a place of sand'; Kabulwebulwe, 'a place of many iguanas'. What $\mathrm{KA}$ - means in Sudanic languages we do not profess to know. We should like to hear from readers who have made a study of African place-names.

\section{Conference of Missionary Societies}

Professor Daryll Forde, Director of the Institute, opened the session on 'The Gospel and Primitive Peoples' at the annual general meeting of the Conference of Missionary Societies of Great Britain and Ireland in June 1947. He indicated some of the difficulties which meet the administrator, the mercantilist, and the missionary called to work among 